\title{
Assessing the influence of oil and grease and salt content on fish canning wastewater biodegradation through respirometric tests
}

\author{
Raquel O. Cristóvão ${ }^{\text {a, }}{ }^{*}$, Victor M.S. Pinto ${ }^{b}$, Ramiro J.E. Martins ${ }^{\text {a, b }}$, José M. Loureiro ${ }^{a}$, \\ Rui A.R. Boaventura a \\ a Laboratory of Separation and Reaction Engineering (LSRE), Associate Laboratory LSRE/LCM, Department of Chemical Engineering, Faculty of Engineering, \\ University of Porto, Rua do Dr. Roberto Frias, 4200-465, Porto, Portugal \\ b Department of Chemical and Biological Technology, Superior School of Technology, Polytechnic Institute of Bragança, Campus de Santa Apolónia, 5301-857 \\ Bragança, Portugal
}

\section{A R T I C L E I N F O}

\section{Article history:}

Received 2 November 2015

Received in revised form

13 April 2016

Accepted 14 April 2016

Available online 22 April 2016

\section{Keywords:}

Fish canning wastewater

Oily wastewater

Saline wastewater

Inhibition

Respirometry

\begin{abstract}
A B S T R A C T
Fish canning industry wastewaters have high organic matter, oil and grease and salt ( $\mathrm{NaCl}) \mathrm{content}$, which make difficult a proper treatment before discharge. In this work, their treatment was evaluated via activated sludge aerobic biological process through respirometric tests. Inhibition was found to be significant for $\mathrm{NaCl}$ concentrations higher than $17.5 \mathrm{~g} / \mathrm{L}$. On the other hand, the oil and grease content affects the wastewater biodegradability in the same way that the organic matter content expressed as chemical oxygen demand: the lower oil and grease and organic matter concentrations, the lower the percentage of wastewater biodegradability. As a final conclusion, the aerobic biological treatment process by activated sludge proved to be appropriate to treat fish canning industrial wastewaters, leading to high organic matter degradation rates (average value of $4900 \mathrm{mg} / \mathrm{g}_{\mathrm{COD}} \cdot \mathrm{d}$ ). Additionally, the experimental results achieved with the respirometric tests may be useful for the design of activated sludge plants to treat this type of wastewaters.
\end{abstract}

(C) 2016 Elsevier Ltd. All rights reserved.

\section{Introduction}

Recently, there has been an increase in the number of fish canning industries across the world. The wastewaters produced in this type of industries vary widely, depending on the production period, on the type of fish and/or on the process used. Their treatment is complex due to their saline nature (they present high $\mathrm{NaCl}$ concentration) and due to the presence of oils and other organic compounds (Cristóvão et al., 2015).

Conventional biological treatment processes, in particular activated sludge systems, are widely used in wastewater treatment plants (WWTPs). However, toxic and inhibitory compounds such as volatile organic compounds (VOCs), salts, heavy metals, oils and greases, aromatic or chlorinated organics are usually found in industrial wastewaters and their negative impact on microorganisms' activity requires specific attention (Ricco et al., 2004). Toxicant effects are quite complex, not easily predictable, and could include biological sludge inhibition, decreasing the organic waste

\footnotetext{
* Corresponding author. Tel.: +351 22041 3606; fax: +351 225081674 .

E-mail address: raquel.cristovao@fe.up.pt (R.O. Cristóvão).
}

biodegradation and leading to the modification of the sludge settleability properties, which often decreases the solid-liquid separation efficiency.

Wastewaters with high salt content are known to be significantly more difficult to treat by conventional biological methods, leading to cells plasmolysis or activity loss (Kargi and Uygur, 1996). Some studies were performed in order to assess the effects of synthetic wastewaters with high salt content on biomass activity (Kokabian et al., 2013; Zhan et al., 2000). Panswad and Anan (1999) showed a reduction on the organic content (in terms of chemical oxygen demand (COD)) removal efficiency from 97 to $60 \%$ as the $\mathrm{NaCl}$ content increased from 0 to $30 \mathrm{~g} / \mathrm{L}$ when treating a synthetic wastewater by an anaerobic/anoxic/aerobic process. Dinçer and Kargi (2001) also reported a decrease of COD removal efficiency when increasing the salt concentration on the biological treatment of a synthetic saline wastewater using a rotating biodisc unit.

Oil and grease $(O \& G)$ are known to be part of wastewater organic composition. However, due to their floating nature, they need to be firstly removed, if no they will affect the oxygen transfer to the wastewater in the aerobic biological treatment. Despite suspended O\&G can be easily removed by physical methods, 
emulsified ones contribute also to biochemical oxygen demand (BOD) and COD and must be treated in an appropriate manner. Once the costs of physicochemical treatments are particularly high, biological treatment processes are also commonly used for this purpose. However, O\&G exact degradation behavior in these treatment processes is not well understood. In biological wastewater treatment systems, O\&G are generally believed to be biodegradable, however they contribute to a lower microbial activity (Sunny and Mathai, 2013) mostly due to accumulation onto the microorganisms by adsorption, precipitation and entrapment mechanisms but also due to the physical barrier that they can create to substrates and products transport (Cavaleiro et al., 2009). Chipasa and Medrzycka (2008) showed that the utilization of microorganisms for lipids complete removal from wastewater is limited. Appling aerobic biological treatment, Primasari et al. (2011) obtained an O\&G removal of ca. 55\% for an oily wastewater from palm oil food industry, while Nakhla et al. (2006) only achieved a COD removal between 19 and $44 \%$ for pet food wastewater with O\&G concentration of up to $22 \mathrm{~g} / \mathrm{L}$. Such discrepancy is caused by long-chain fatty acid adsorption onto sludge. All these facts suggest the development of more robust biological systems for fish canning industry wastewaters treatment. The treatment effectiveness depends on the wastewater characteristics and on the viable microorganisms' amount present in the biological reactor.

The present work intends to evaluate the activated sludge biological process for real fish canning industrial wastewaters treatment, as well as, to study the inhibitory effects of some characteristic constituents on their biodegradability level. To our knowledge no report was found regarding this type of study with real fish canning industrial wastewaters. For this purpose, first the composition variability of this type of wastewaters was evaluated through seasonal sampling and extensive physicochemical characterization of the collected samples. Subsequently, the wastewater biodegradability under aerobic biological conditions was evaluated by respirometry, analyzing the influence of organic matter, salinity and oil and grease content in the wastewater. Using respirometric tests, carried out in new technologically advanced respirometers, it is possible to analyze the biodegradation process, through kinetic constants determination and treatment process modeling, as well as, wastewater toxicity assessment, activated sludge activity and nitrification capacity evaluation, etc (Hoffman et al., 1997; Mahendraker and Viraraghavan, 1995; Shogren et al., 2004). This way, respirometry is an advantageous technique to identify the compounds that potentially have an adverse effect on the wastewater treatment process (Hufschmid et al., 2003; Kungolos, 2005).

\section{Material and methods}

First, several wastewater samples from a fish canning industry were collected and characterized. After that, the corresponding biodegradability and toxicity were assessed through different types of respirometric tests with activated sludge, using a BM-T Advance sludge respirometer (SURCIS L., Spain).

\subsection{Wastewater sample collection and characterization}

The wastewater samples were collected in a selected fish canning company of northern Portugal, according to a sampling program designed for its correct characterization. This way, eleven samples were collected at different time periods (from February to June 2014) and characterized in terms of several physicochemical parameters. Three sampling types were adopted: 3 grab wastewater samples, collected at two different days, one in the morning, somewhere between 10 and $10 \mathrm{~h} 30$, and another two in the afternoon, between 16 and 16h30; 7 daily composite samples and 1 weekly composite sample. Daily composite samples were prepared by grab samples addition ( 2 L each one) collected every $2 \mathrm{~h}$ between $9 \mathrm{~h} 30$ and $17 \mathrm{~h} 30$ (corresponding to the $8 \mathrm{~h}$ of a working day), making a total of $10 \mathrm{~L}$. The weekly composite sample was prepared by daily effluent collection every 2 h, between $9 \mathrm{~h} 30$ and $17 \mathrm{~h} 30$, making a daily total volume of $5 \mathrm{~L}$. At the end of the week, $2 \mathrm{~L}$ were removed from each of the five daily composite samples and mixed in another container, representing the final weekly sample. The grab samples and the composite ones, during and after preparation, were kept in a refrigerator before analysis.

Standard Methods for the Examination of Water and Wastewater (APHA, 2012) were adopted for the measurement of total suspended solids (TSS), volatile suspended solids (VSS), dissolved organic carbon (DOC), chemical oxygen demand (COD), biochemical oxygen demand (BOD), oil and grease (O\&G), total phosphorus $\left(P_{\text {total }}\right)$, total soluble nitrogen $\left(\mathrm{N}_{\text {total soluble }}\right)$. For each parameter, duplicate analyses were made. For DOC measurements a Shimadzu 5000A Total Organic Carbon analyser was used. The reported values represent the average of at least two measurements; in most cases each sample was injected three times, validation being performed by the apparatus only if the coefficient of variation (CV) was smaller than $2 \%$.

The $\mathrm{pH}$ was measured using a selective electrode (Hanna Instruments HI 1230) and a pH meter (Hanna instruments HI 8424) and the conductivity at $20^{\circ} \mathrm{C}$ was determined using a conductivity probe (WTW TetraCon 325) and a conductivity meter (WTW LF538).

Anions were measured by ion chromatography (Dionex ICS2100) using a Dionex Ionpac (column AS 11-HC $4 \times 250 \mathrm{~mm}$; suppressor ASRS $3004 \mathrm{~mm}$ ). Cations were analyzed also by ion chromatography (Dionex DX-120), using a Dionex Ionpac (column CS12A $4 \times 250 \mathrm{~mm}$; suppressor: CSRS $3004 \mathrm{~mm}$ ). Isocratic elution was done with $\mathrm{NaOH} 30 \mathrm{mM} /$ methanesulfonic acid $20 \mathrm{mM}$ at a flow rate of $1.5 / 1.0 \mathrm{~mL} / \mathrm{min}$ for anions/cations analysis, respectively.

\subsection{Biological sludge source}

The aerobic activated sludge was obtained from Freixo Municipal Wastewater Treatment Plant (Portugal) and was allowed to air for $24 \mathrm{~h}$ before being used in the tests, in order to remove the residual COD in the liquid phase.

The activated sludge was analyzed for volatile suspended solids (VSS) through the standard procedure reported in Standard Methods (APHA, 2012).

\subsection{Aerobic respirometric tests}

Respirometric tests with activated sludge were carried out in a BM-T Advance sludge respirometer (SURCIS L., Spain) consisting of a $1 \mathrm{~L}$ capacity biological reactor with temperature and $\mathrm{pH}$ control and dissolved oxygen meter.

The samples biodegradability and toxicity were determined through two different types of respirometric tests: static oxygen uptake rate (OUR) tests to evaluate the biomass specific oxygen consumption rate, allowing to analyze the toxic effects of certain compounds on the microbial activity; dynamic respiration rate $(R)$ tests also to determine the organic matter degradation rate and the amount of degraded organic matter. Unlike OUR tests, during the $\mathrm{R}$ tests the peristaltic pump and the aeration never stop and the test is not over until all the biodegradable material is completely consumed. The choice between static and dynamic respirometric tests should be decided on a case-by-case basis. In fact, dynamic respirometry allows for the determination of parameters in a larger range of experimental conditions, but is more complex to interpret and requires more time for analysis in respect to static tests. On the 
other hand, static respirometry is simpler, allowing for a direct determination of the respiration rate under actual conditions but is limited to a relatively short dissolved oxygen concentration range before oxygen may become limiting. This way, it is important to evaluate both methods to decide which is the best to apply in the case under study.

For OUR biodegradability measurements, the respirometer was loaded with $700 \mathrm{~mL}$ of activated sludge from the Freixo municipal wastewater treatment plant (Portugal). In order to inhibit the nitrification process and only measure the oxygen consumption by the heterotrophic bacteria, $3 \mathrm{mg}$ of $\mathrm{N}$-allythiourea per gram of volatile suspended solids (VSS) was added to the activated sludge. The experiments were performed at $20^{\circ} \mathrm{C}$ and $\mathrm{pH}$ of $6.5-7.5 .30 \mathrm{~mL}$ of each sample were added to the respirometer vessel, the aeration and agitation were stopped and the oxygen consumption was monitored automatically during the assay, until dissolved oxygen values lower than 1 were reached. These tests were carried out using sodium acetate as a reference substrate to compare with the sample under study. The biodegradability of the sample was determined by Eq. (1):

OUR_Biodegradability $(\%)=\frac{O U R_{\text {sample }}}{O U R_{\text {reference }}} \times 100$

where OUR $R_{\text {reference }}$ is the oxygen uptake rate of the reference sample (sodium acetate) $\left(\mathrm{mgO}_{2} / \mathrm{L} \mathrm{h}\right)$ and $O U R_{\text {sample }}$ is the oxygen uptake rate of the sample $\left(\mathrm{mgO}_{2} / \mathrm{L} \mathrm{h}\right)$.

For biodegradability measurements through $\mathrm{R}$ tests, the respirometer was also loaded with $700 \mathrm{~mL}$ of activated sludge from the same WWTP. The $3 \mathrm{mg}$ of N-allythiourea per gram of volatile solids were also added in order to inhibit the nitrification process. The experiments were performed at $20{ }^{\circ} \mathrm{C}$ and $\mathrm{pH}$ of $6.5-7.5$ under continuous aeration and agitation. $30 \mathrm{~mL}$ of each sample was added to the respirometer vessel and the oxygen consumption was monitored automatically during the assay. At the end of the test, the respirometer software gives the biodegradable fraction of the sample (bCOD) based on the total oxygen consumption measured and the normal biomass yield ( 0.67 gCODbiomass/gCODdegraded, as mentioned in the respirometer manual) for activated sludge from conventional municipal wastewater treatment plants. The sample biodegradability based on $\mathrm{R}$ tests is calculated through Eq. (2):

$R_{-}$Biodegradability $(\%)=\frac{b C O D}{C O D}$

The toxicity of the wastewater samples was evaluated through OUR tests by comparing the oxygen uptake rate from an assay performed with the sludge and $30 \mathrm{~mL}$ of a biodegradable reference substrate and the oxygen uptake rate from another assay with sludge previously being the contact with $30 \mathrm{~mL}$ of the wastewater sample and $30 \mathrm{~mL}$ of the same reference sample. The reference substrate used was sodium acetate in an amount corresponding to the dissolved organic carbon (DOC) of each sample under study. Thus, the toxicity percentage was evaluated as follows:

OUR_Toxicity $(\%)=\frac{O U R_{\text {reference }}-O U R_{\text {sample }+ \text { reference }}}{O U R_{\text {reference }}} \times 100$

where $O U R_{\text {sample }}+$ reference is the oxygen uptake rate of the reference sample (sodium acetate) achieved with a sludge that already contacted with the wastewater sample and OUR reference is the oxygen uptake rate of the reference sample.

The toxicity of the wastewater samples was also evaluated through $\mathrm{R}$ tests by comparing the bacterial activity in two assays: one containing the sludge and $30 \mathrm{~mL}$ of a biodegradable reference substrate and another containing the sludge and $30 \mathrm{~mL}$ of the target sample. In all cases, the tests were extended until the biomass reached the maximum respiration rate $\left(R s_{\max }, \mathrm{mgO}_{2} / \mathrm{L} \mathrm{h}\right)$ and the toxicity percentage of each sample can be expressed quantitatively according to the following equation:

$R_{-} \operatorname{Toxicity}(\%)=\left(1-\frac{R s_{\text {max_sample }}}{R s_{\text {max_reference }}}\right) \times 100$

where $R s_{\text {max_sample }}$ is the maximum dynamic respiration rate relative to the sample assay and $R s_{\text {max_reference }}$ is the maximum dynamic respiration rate relative to the reference assay (sodium acetate).

To evaluate the effect of $\mathrm{NaCl}$ and $\mathrm{O} \& \mathrm{G}$ content on the wastewater organic matter biodegradation, two of the samples under study were chosen: one with low $\mathrm{NaCl}$ and $\mathrm{O \& G}$ concentrations $(03 / 31 / 2014 \mathrm{C})$, to be possible to add different $\mathrm{NaCl}$ amounts and see the isolated effect of the $\mathrm{NaCl}$ concentration variation and another one with a high $\mathrm{O} \& \mathrm{G}$ amount and a low $\mathrm{NaCl}$ concentration $(04 / 14 / 2014 \mathrm{C})$ in order to be able to remove O\&G from the wastewater and to study lower $O \& G$ concentrations.

This way, different $\mathrm{NaCl}$ quantities were added to the 03/31/ $2014 \mathrm{C}$ wastewater sample (containing originally $4 \mathrm{~g} / \mathrm{L}$ of $\mathrm{NaCl}$ and $1.9 \mathrm{~g} / \mathrm{L}$ of $\mathrm{O \& G}$ ) in order to obtain wastewater samples with $8,17.5$ and $30 \mathrm{~g} / \mathrm{L}$ of $\mathrm{NaCl}$ (dosages within the range found in wastewater characterization) to study the salinity effects on the wastewater biodegradability and toxicity through $\mathrm{R}$ tests. Similarly, different quantities of floatable O\&G were removed from the 04/14/2014 C wastewater sample containing originally $11.1 \mathrm{~g} / \mathrm{L}$ of O\&G, achieving wastewater samples with 7.5 and $3.6 \mathrm{~g} / \mathrm{L}$ of $\mathrm{O} \& \mathrm{G}$, also to assess $\mathrm{O} \& \mathrm{G}$ effects on the results from $\mathrm{R}$ tests.

Biodegradability percentage data were utilized to build the biodegradability percentage curve as a function of the contaminant $(\mathrm{NaCl}$ and $\mathrm{O \& G}$ ) concentration tested.

Finally, the reaction kinetics was investigated by fitting the experimental data of samples degradation to a pseudo-first order kinetic equation: $\ln \left(C / C_{0}\right)=-k \times t$, where $C$ represents the biodegradable organic matter concentration $(\mathrm{mg} / \mathrm{L})$ at time $t(\mathrm{~h}), C_{0}$ is the initial biodegradable organic matter concentration $(\mathrm{mg} / \mathrm{L})$ and $k$ is the reaction kinetic constant $\left(\mathrm{h}^{-1}\right)$.

Each activated sludge sample was used only for one test: in other words, the different $\mathrm{NaCl}$ or O\&G concentrations were tested with renewed sludge samples, to avoid partial acclimatization of the biomass to the contaminant and consequent possible underestimation of the toxicity effects. In order to ensure the reproducibility of the measurements, all tests referring to the same contaminant were done with the same stock of activated sludge. Different stocks of municipal sludge were used during the whole experimental period in order to avoid using the sludge stored for too long periods of time.

\section{Results and discussion}

In the subsections below we describe and discuss the results from the characterization of the fish canning wastewater samples, as well as the ones obtained from the respirometric tests.

\subsection{Characterization of fish canning wastewater}

Wastewater characterization is a critical factor in establishing an effective management strategy or treatment process. The fish canning wastewater characteristics vary according to the production process in a specific fish canning industry. In order to obtain a representative set of information on effluent properties, several 
samples were collected at different times and analyzed. The data from the analysis of 23 parameters in 11 wastewater samples are presented in Table 1. It has to be noted that data below a detection threshold was replaced by the equipment detection limit. As expected, the results obtained show that the characteristics of the fish canning industrial wastewater under study present high variability, despite the fact that all samples were taken from a common wastewater reception well. The different wastewater streams come mainly from the following processes: brine water from fish cleaning; melted ice contaminated with blood and defrost water; water containing blood, guts and fish waste, generated in the eviscerating stage; blood, grease and liquid waste from the cooking step; oils and fish remains from sauces filling stage; water from cans, equipment and facilities washing steps. Thus, the volume and characteristics of the final effluent change significantly throughout the day, depending on the streams that are being released. According to information from the fish canning company, several fish types can be processed every day, namely, sardines, mackerel and tuna. This way, it is hard to know what is the contribution of each species to the final effluent characteristics.

As it is possible to observe on Table 1, the wastewaters from this industrial company present high content of solids (TSS, VSS), organic matter $\left(\mathrm{COD}, \mathrm{BOD}_{5}\right)$, oil and grease $(\mathrm{O} \& \mathrm{G})$ and salt $(\mathrm{NaCl})$, which is in accordance with the characteristics already reported by other authors for fish processing industry effluents (Chowdhury et al., 2010).

In the case of composite samples it would be expected that the parameters do not differ greatly from sample to sample, being, this way, more representative of the effluent composition. However, this was not observed, confirming again the high variability of fish canning industry wastewaters not only during the day but from day to day.

Table 2 presents the mean, the respective standard deviation, the minimum and the maximum values obtained from the characterization of all samples. Again, the high $\mathrm{BOD}_{5}$ and $\mathrm{COD}$ values show effluent's strong contamination with organic matter. As was aforementioned, the wastewater presents also high values of TSS, $O \& G$ and salt content (analyzed in terms of $\mathrm{Cl}^{-}$and $\mathrm{Na}^{+}$concentrations and conductivity values). Typically the $\mathrm{pH}$ of fish processing industry wastewaters varies between 5.7 and 7.4, being on average equal to 6.4 (Technical Report Series FREMP, 1994). In this case, the effluent $\mathrm{pH}$ ranged between 5.6 and 9.6, with an average value of 6.8 , close to the value reported in the literature (Technical Report Series FREMP, 1994). This pH average value indicates that the wastewater is favorable for biological treatment. Suspended solids are one of the contaminants potentially causing more impact on the environment. TSS concentration in this type of effluents is generally high, between 2000 and $5000 \mathrm{mg} / \mathrm{L}$ (Novatec, 1994; Prasertan et al., 1994), which also happened in this study, where the TSS mean value was $2988 \mathrm{mg} / \mathrm{L}$. The COD and $\mathrm{BOD}_{5}$ values varied between 3314 and $17,048 \mathrm{mg} / \mathrm{L}$ and $2420-13,626 \mathrm{mg} / \mathrm{L}$. The ranges found confirm, once again, the high variability of this type of wastewaters. According to the literature, the organic matter content in fish canning industry wastewaters is in the range of $10,000-50,000 \mathrm{mg} / \mathrm{L}$ (Chowdhury et al., 2010). Fish processing wastewater COD:BOD 5 ratios varies widely within and among processing plants ranging from $1.1: 1$ to 3:1 (Technical Report Series FREMP, 1994), which was also verified in this study, where an average ratio of 1.7:1 was found. This ratio indicates that the organic matter in the wastewater is biodegradable. The O\&G content shows an average value of $3933 \mathrm{mg} / \mathrm{L}$, value between the values reported in literature $(20-4000 \mathrm{mg} / \mathrm{L})$ (Chowdhury et al., 2010). The average concentration of $\mathrm{NaCl}$ in the effluent is about $10,800 \mathrm{mg} / \mathrm{L}$. Although typical values of $\mathrm{NaCl}$

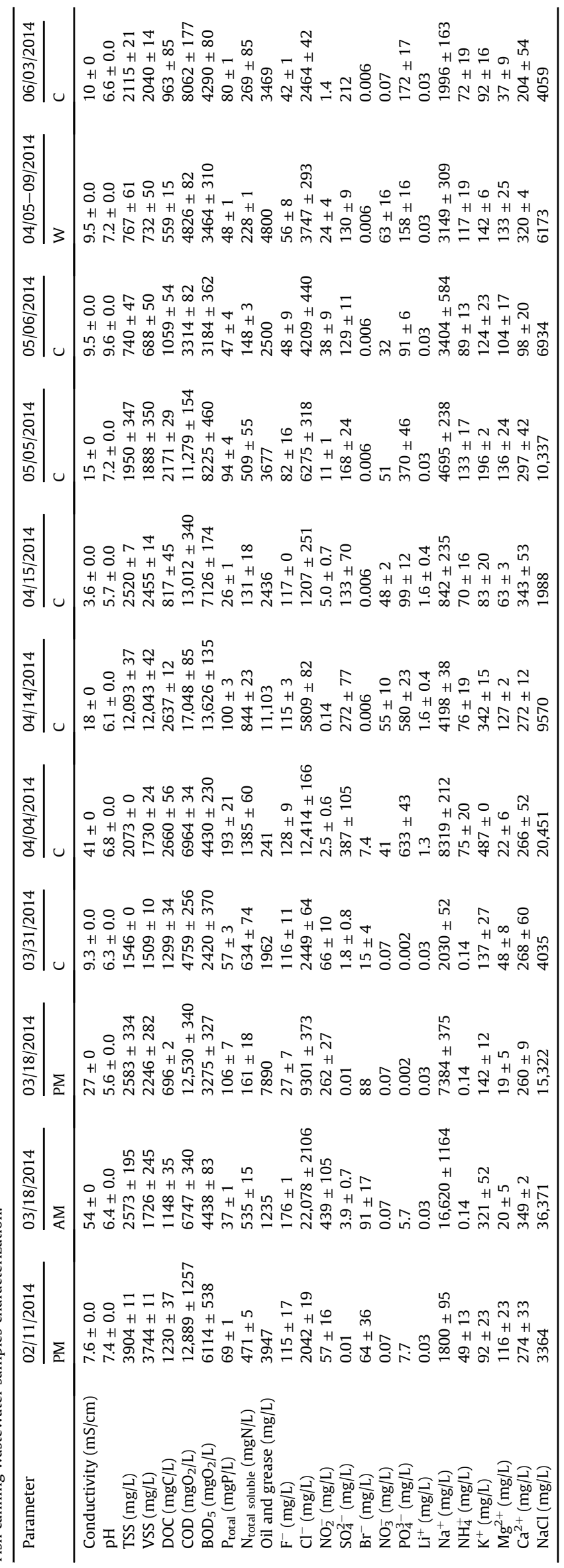


Table 2

Seasonal variation of fish canning wastewater characteristics using 11 wastewater samples.

\begin{tabular}{lcccc}
\hline Parameter & $\begin{array}{l}\text { Average of } 11 \\
\text { samples }\end{array}$ & $\begin{array}{c}\text { Standard } \\
\text { deviation }\end{array}$ & Minimum & Maximum \\
\hline Conductivity $(\mathrm{mS} / \mathrm{cm})$ & 19 & 15 & 3.6 & 54 \\
$\mathrm{pH}$ & 6.8 & 1 & 5.6 & 9.6 \\
$\mathrm{TSS}(\mathrm{mg} / \mathrm{L})$ & 2988 & 3001 & 740 & 12,093 \\
$\mathrm{VSS}(\mathrm{mg} / \mathrm{L})$ & 2800 & 3028 & 688 & 12,043 \\
$\mathrm{DOC}(\mathrm{mgC} / \mathrm{L})$ & 1385 & 717 & 559 & 2660 \\
$\mathrm{COD}\left(\mathrm{mgO}_{2} / \mathrm{L}\right)$ & 9221 & 4166 & 3314 & 17,048 \\
$\mathrm{BOD}_{5}(\mathrm{mgO} / \mathrm{L})$ & 5508 & 3077 & 2420 & 13,626 \\
$\mathrm{P}_{\text {total }}(\mathrm{mgP} / \mathrm{L})$ & 78 & 44 & 26 & 193 \\
$\mathrm{~N}_{\text {total soluble }}(\mathrm{mgN} / \mathrm{L})$ & 483 & 359 & 131 & 1385 \\
$\mathrm{Oil}^{-} \mathrm{and} \mathrm{grease}(\mathrm{mg} / \mathrm{L})$ & 3933 & 2972 & 241 & 11,103 \\
$\mathrm{~F}^{-}(\mathrm{mg} / \mathrm{L})$ & 93 & 43 & 27 & 176 \\
$\mathrm{Cl}^{-}(\mathrm{mg} / \mathrm{L})$ & 6545 & 5873 & 1207 & 22,078 \\
$\mathrm{NO}_{2}^{-}(\mathrm{mg} / \mathrm{L})$ & 82 & 134 & 0.1 & 439 \\
$\mathrm{SO}_{4}^{2-}(\mathrm{mg} / \mathrm{L})$ & 131 & 121 & 0.0 & 387 \\
$\mathrm{Br}^{-}(\mathrm{mg} / \mathrm{L})$ & 24 & 36 & 0.0 & 91 \\
$\mathrm{NO}_{3}^{-}(\mathrm{mg} / \mathrm{L})$ & 26 & 25 & 0.1 & 63 \\
$\mathrm{PO}_{4}^{3-}(\mathrm{mg} / \mathrm{L})$ & 192 & 221 & 0.0 & 633 \\
$\mathrm{Li}^{+}(\mathrm{mg} / \mathrm{L})$ & 0.0 & 1 & 0.0 & 2 \\
$\mathrm{Na}^{+}(\mathrm{mg} / \mathrm{L})$ & 4949 & 4304 & 842 & 16,620 \\
$\mathrm{NH}_{4}^{+}(\mathrm{mg} / \mathrm{L})$ & 62 & 44 & 0.1 & 133 \\
$\mathrm{~K}^{+}(\mathrm{mg} / \mathrm{L})$ & 196 & 425 & 83 & 487 \\
$\mathrm{Mg}^{2+}(\mathrm{mg} / \mathrm{L})$ & 75 & 67 & 98 & 136 \\
$\mathrm{Ca}^{2+}(\mathrm{mg} / \mathrm{L})$ & 268 & & & 349 \\
\hline & & 46 & 19 & \\
\hline
\end{tabular}

concentration in similar effluents were not referenced in the literature, this parameter is very important, since high salt content can inhibit the biological processes.

Table 3 presents some ratios between parameters, which are important for anticipating the results of aerobic treatment tests. The ratio $\mathrm{BOD}_{5} / \mathrm{COD}$ is commonly used to evaluate the wastewater biodegradability. According to Ballesteros Martín et al. (2010), biodegradability values of $30 \%$ or higher correspond to samples classified as very biodegradable and can effectively be treated by a biological process, a value between 10 and 30\% means that the sample is biodegradable, whereas values lower than $5 \%$ indicate that the sample is not biodegradable (values between $5 \%$ and $10 \%$ indicate samples with low biodegradability). As shown in Table 3, all samples proved to be very biodegradable, as expected, since all $\mathrm{BOD}_{5} / \mathrm{COD}$ ratio values are above $30 \%$, with the exception of $03 / 18 /$ 2014 PM sample, which exhibits a biodegradability of $26 \pm 3 \%$.

The $\mathrm{BOD}_{5}: \mathrm{N}: \mathrm{P}$ ratio is of utmost importance to predict the success of biodegradation under aerobic conditions. For an effective aerobic treatment, as a general rule, the wastewater nutrients weight ratio must be $\mathrm{BOD}_{5}: \mathrm{N}: \mathrm{P}=100: 5: 1$, which means that, for each $100 \mathrm{~g}$ of $\mathrm{BOD}_{5}$ present in the effluent, $5 \mathrm{~g}$ of $\mathrm{N}$ and $1 \mathrm{~g}$ of $\mathrm{P}$ are needed (Metcalf and Eddy, 1995). The lack of $\mathrm{N}$ and $\mathrm{P}$ gives rise to scattered flakes formation and to the growth of filamentous

Table 3

Important characteristic ratios of fish canning industry wastewaters.

\begin{tabular}{llll}
\hline \multirow{2}{*}{ Date } & \multicolumn{3}{l}{ Ratios } \\
\cline { 2 - 4 } & $\mathrm{BOD}_{5} / \mathrm{COD}(\%)$ & $\mathrm{BOD}_{5} / \mathrm{N} / \mathrm{P}$ & $\mathrm{Cl}^{-} / \mathrm{Na}^{+}$ \\
\hline $02 / 11 / 2014 \mathrm{PM}$ & $47 \pm 9$ & $100 / 7.7 / 1.1$ & 1 \\
$03 / 18 / 2014 \mathrm{AM}$ & $66 \pm 5$ & $100 / 12.1 / 0.8$ & 0.9 \\
$03 / 18 / 2014 \mathrm{PM}$ & $26 \pm 3$ & $100 / 4.9 / 3.2$ & 0.8 \\
$03 / 31 / 2014 \mathrm{C}$ & $51 \pm 11$ & $100 / 26.2 / 2.4$ & 0.8 \\
$04 / 04 / 2014 \mathrm{C}$ & $64 \pm 4$ & $100 / 31.3 / 4.4$ & 1 \\
$04 / 14 / 2014 \mathrm{C}$ & $80 \pm 1$ & $100 / 6.2 / 0.7$ & 0.9 \\
$04 / 15 / 2014 \mathrm{C}$ & $55 \pm 3$ & $100 / 1.8 / 0.4$ & 0.9 \\
$05 / 05 / 2014 \mathrm{C}$ & $73 \pm 5$ & $100 / 6.2 / 1.1$ & 0.9 \\
$06 / 05 / 2014 \mathrm{C}$ & $96 \pm 13$ & $100 / 4.6 / 1.5$ & 0.8 \\
$04 / 05-09 / 2014 \mathrm{~W}$ & $72 \pm 8$ & $100 / 6.6 / 1.4$ & 0.8 \\
$06 / 03 / 2014 \mathrm{C}$ & $53 \pm 2$ & $100 / 6.3 / 1.9$ & 0.8 \\
\hline
\end{tabular}

bacteria, which affect the wastewater treatment efficiency. According to the results present in Table 3, the 04/15/2014 C sample is the only one that does not have the required amount of $\mathrm{N}$ and $\mathrm{P}$, which could impair the performance of the aerobic biological treatment. This way, in general, the results indicate that almost all samples meet the minimum nutrient ratios necessary for an effective biological treatment.

The $\mathrm{Cl} / \mathrm{Na}$ ratio was also determined in order to check if $\mathrm{Cl}^{-}$and $\mathrm{Na}^{+}$ions are only derived from sodium chloride salt $(\mathrm{NaCl})$ or if they derive from other salts. Taking into account the values presented in Table 3 one can conclude that in most samples the ions sodium and chloride are derived only from $\mathrm{NaCl}$ salt, since their molar ratio is approximately $1: 1$. However, the ratio is lower than 1 in some samples, which means that the sodium ions may come from other salts, such as sodium nitrate $\left(\mathrm{NaNO}_{3}\right)$, sodium nitrite $\left(\mathrm{NaNO}_{2}\right)$, sodium bromide $(\mathrm{NaBr})$ and sodium sulfate $\left(\mathrm{Na}_{2} \mathrm{SO}_{4}\right)$.

\subsection{Respirometry assays}

Respirometry is a technique widely used to evaluate aerobic biodegradation of certain substrates. Thus, respirometric tests with activated sludge were applied to wastewater samples from the selected fish canning industry at northern Portugal. Firstly, the samples biodegradability (Eq. (1)) and toxicity (Eq. (3)) were evaluated through OUR tests. It has to be noted that, throughout the respirometric tests, biomass oxygen consumption was continuously recorded. In these tests, the oxygen supply is stopped and the OUR values are obtained only for the initial degradation phase of the reference substance, sodium acetate, and of each of the samples under study. By observing the results present in Table 4, it is possible to verify that according to OUR tests, all samples are $100 \%$ biodegradable. However, it must be noted that, in the OUR tests, since the oxygen supply is stopped, it is not guaranteed that the samples were totally degraded and the biodegradability values may have a certain calculation error.

To find any chronic toxicity through OUR tests, sodium acetate was added after biomass exposure to wastewater samples, to evaluate again the biomass response. Fig. 1 shows the OUR curves obtained in the OUR tests performed to determine the toxicity of 03/31/2014 C sample, as typical oxygen concentration profiles observed in the respirometric tests for all wastewater samples under study. It has to be noted that the OUR values of the sodium acetate solution varied along the experimental study due to the activity variation of the different stocks of the biological sludge. In the specific case of $03 / 31 / 2014 \mathrm{C}$ sample, comparing the sodium acetate curve and the response of the same substrate after exposure of the biomass to wastewater sample, an OUR decrease of about $27.5 \%$ was detected (OUR_Toxicity (\%) in Table 4). This result means an inhibitory effect on the biomass activity. OUR decrease was well detected just after the sample addition, no lag phase was observed. This is a good point for process control: early detection of toxicants allows the prompt intervention of opportune control strategies to reduce the biomass-toxicant contact time (Ricco et al., 2004). The results presented in Table 4 show that, with the exception of two samples, 03/18/2014 AM and 03/31/2014 C, that exhibited some toxicity ( $2.3 \%$ and $27.5 \%$, respectively), the biomass respirometric activity was normal, completely consuming the biodegradable substrate (according to the dissolved oxygen recorded). This means that continued exposure of the biomass to fish canning wastewater, in general, does not affect its activity.

In order to confirm the results from OUR tests, the biodegradability and toxicity of all samples were also assessed through $\mathrm{R}$ tests (Eq. (2) and (4), respectively). The values obtained correspond to the entire degradation of the sample, giving more reliable results than those obtained in OUR tests. This can be observed in Fig. 2, 

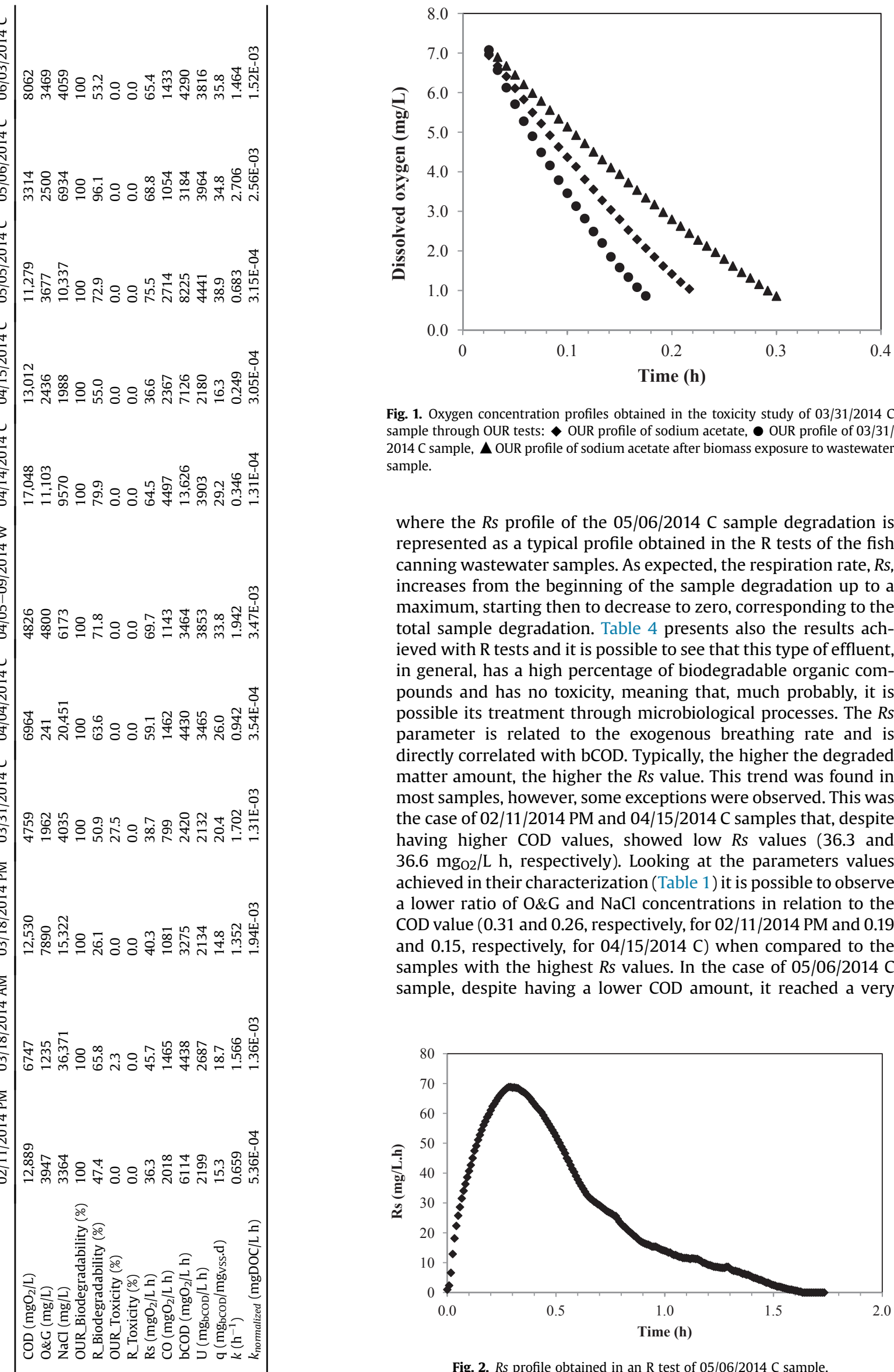

Fig. 1. Oxygen concentration profiles obtained in the toxicity study of $03 / 31 / 2014 \mathrm{C}$ sample through OUR tests: $\bullet$ OUR profile of sodium acetate, - OUR profile of 03/31/ 2014 C sample, $\boldsymbol{\Delta}$ OUR profile of sodium acetate after biomass exposure to wastewater sample.

where the Rs profile of the 05/06/2014 C sample degradation is represented as a typical profile obtained in the $\mathrm{R}$ tests of the fish canning wastewater samples. As expected, the respiration rate, $R s$, increases from the beginning of the sample degradation up to a maximum, starting then to decrease to zero, corresponding to the total sample degradation. Table 4 presents also the results achieved with $\mathrm{R}$ tests and it is possible to see that this type of effluent, in general, has a high percentage of biodegradable organic compounds and has no toxicity, meaning that, much probably, it is possible its treatment through microbiological processes. The Rs parameter is related to the exogenous breathing rate and is directly correlated with bCOD. Typically, the higher the degraded matter amount, the higher the Rs value. This trend was found in most samples, however, some exceptions were observed. This was the case of 02/11/2014 PM and 04/15/2014 C samples that, despite having higher COD values, showed low Rs values (36.3 and $36.6 \mathrm{mg}_{\mathrm{O} 2} / \mathrm{L} \mathrm{h}$, respectively). Looking at the parameters values achieved in their characterization (Table 1 ) it is possible to observe a lower ratio of $\mathrm{O} \& \mathrm{G}$ and $\mathrm{NaCl}$ concentrations in relation to the COD value ( 0.31 and 0.26 , respectively, for $02 / 11 / 2014 \mathrm{PM}$ and 0.19 and 0.15 , respectively, for $04 / 15 / 2014 \mathrm{C}$ ) when compared to the samples with the highest $R s$ values. In the case of 05/06/2014 C sample, despite having a lower COD amount, it reached a very

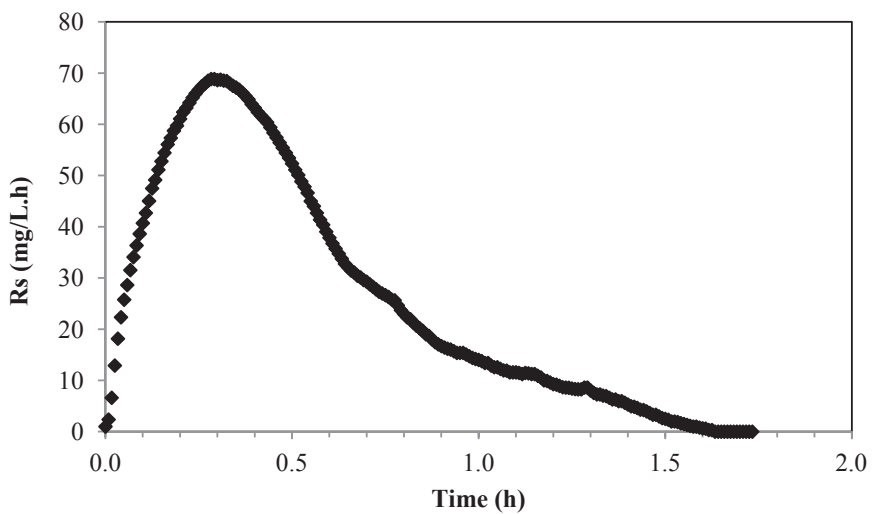

Fig. 2. Rs profile obtained in an $\mathrm{R}$ test of 05/06/2014 C sample. 
high $R s$ value $\left(68.8 \mathrm{mg}_{02} / \mathrm{L} \mathrm{h}\right)$, since the O\&G:COD and $\mathrm{NaCl}: \mathrm{COD}$ ratios are higher ( 0.75 and 2.09 , respectively). So, it can be concluded that the higher the ratios O\&G:COD and $\mathrm{NaCl}: \mathrm{COD}$, the higher the value of Rs. This can be confirmed by later experiments for the evaluation of O\&G and $\mathrm{NaCl}$ concentrations influence. The $\mathrm{CO}$ value indicates the consumed oxygen in the sample organics oxidation, being directly proportional to the degraded COD amount.

The $U$ parameter corresponds to the bCOD degradation rate $\left(\mathrm{mg}_{\mathrm{bCOD}} / \mathrm{L} \mathrm{h}\right.$ ) and the $q$ parameter (Eq. (6)) corresponds to the specific bCOD degradation rate $\left(\mathrm{mg}_{\mathrm{bCOD}} / \mathrm{mg}_{\mathrm{vss}} \cdot \mathrm{d}\right)$ and are determined by Eqs. (5) and (6), respectively:

$U=\frac{S b}{T} \times \frac{S_{o}}{K_{o}+S_{o}}$

Where $S_{0}=b C O D \times D, D=V_{f} /\left(V_{f}+V_{m}\right) \times\left(V_{m} / 1000\right), V_{m}$ is the sample volume utilized in the test $(\mathrm{mL}), V_{f}$ is the sludge volume utilized in the test $(\mathrm{mL}), T$ is the complete test time $(\mathrm{h}), S_{0}$ is the dissolved oxygen average along the aerobic activated sludge process $\left(\mathrm{mg}_{\mathrm{O} 2} / \mathrm{L}\right)$ and $K_{0}$ is equal to 0.2 .

$q=24 \times \frac{U}{V S S}$

These two parameters are related to each other through VSS value, varying in the same proportion, but with a constraint: the activated sludge used in each sample test was not always the same. The $U$ parameter is also related to $R s$ and varies according to the ratios O\&G:COD and $\mathrm{NaCl}: \mathrm{COD}$ too. In general, the samples in which the ratio O\&G:COD is higher than the ratio $\mathrm{NaCl}: \mathrm{COD}$, show higher organic matter degradation rates, since a larger part of O\&G contributes to the wastewater organic matter (Sunny and Mathai, 2013) and the $\mathrm{NaCl}$ is known to be an inhibiting factor of biological treatment processes (Pernetti and Di Palma, 2005). Chipasa and Medrzycka (2008) carried out studies to characterize the transformation of lipids in activated sludge under aerobic conditions. However they found that the overall residual lipid content could not be reduced to values below $300 \mathrm{mg} / \mathrm{L}$ from an initial content of $2000 \mathrm{mg} / \mathrm{L}$, showing that the use of microbial activity for lipids complete removal is limited, being necessary the development of new treatment methods.

The kinetic parameter $k$ was determined by fitting the experimental data of samples degradation to a pseudo-first order kinetic equation. From the values obtained (Table 4), it is possible to see that the lower $k$ value corresponds to the sample 04/15/2014 C, the same sample that does not meet the minimum nutrients ratio $\left(\mathrm{BOD}_{5}: \mathrm{N}: \mathrm{P}\right)$ required. This kinetic constant varies also with $\mathrm{O} \& \mathrm{G}$ and $\mathrm{NaCl}$ proportions regarding the $\mathrm{COD}$ value. So, it can be normalized by the initial Dissolved Organic Carbon (DOC) value, thus considering only the soluble organic substances, since the samples are filtered to DOC determination, trying to remove, at the same time, the particulate matter influence on COD and O\&G values. Analyzing the values of the normalized kinetic constant presented in Table 4, it is possible to conclude that the lowest value is still that of the sample referred above. This finding was expected since $O \& G$ in the wastewater is essentially emulsified and the COD is almost totally soluble. According to Ramalho (1977), the kinetic constant for domestic sewage biodegradation varies between 0.017 and $0.03 \mathrm{mg}_{\mathrm{SSV}}^{-1} \mathrm{~L} \mathrm{~d}^{-1}$. In order to be possible to compare the kinetic constant obtained in this work with those reported in the literature, the $k$ average value was divided by the VSS concentration used in respirometric assays, that varied in the range of $2500-3000 \mathrm{mg} / \mathrm{L}$. Considering the average value of $2750 \mathrm{mg} / \mathrm{L}$ it was achieved a $k$ average value for the wastewater samples under study of $0.01 \mathrm{mg}_{\mathrm{SSV}}^{-1} \mathrm{~L} \mathrm{~d}^{-1}$, value below of the one verified to the domestic sewage degradation, probably due to the inhibition factors mentioned above.

From Table 4 it can be concluded that the O\&G and $\mathrm{NaCl}$ concentrations influence the organic matter degradation of fish canning wastewaters through aerobic biological suspended-growth processes. In order to verify these influences, two wastewater samples were selected: one with a low $\mathrm{NaCl}$ concentration and an amount of O\&G not too high, in order to be possible to add different $\mathrm{NaCl}$ amounts to obtain different concentrations, keeping the same values for the remaining parameters; and another sample with a large $\mathrm{O} \& \mathrm{G}$ amount and a low $\mathrm{NaCl}$ concentration in order to be able to remove some $O \& G$ and obtain also different $O \& G$ concentrations in the wastewater. Thus, these samples were modified aiming at varying only one parameter at each time, in order to be able to study the influence of both parameters individually on the organic matter degradation by an aerobic activated sludge process.

The sample selected to study the $\mathrm{NaCl}$ dosage variation was the $03 / 31 / 2014 \mathrm{C}$. This sample has a low $\mathrm{NaCl}$ concentration, in the order of $4035 \mathrm{mg} / \mathrm{L}$, and also a low content of O\&G, about $1962 \mathrm{mg} /$ L. Different quantities of $\mathrm{NaCl}$ were then added to the wastewater sample in order to attain $8000,17,500$ and $30,000 \mathrm{mg} / \mathrm{L} \mathrm{NaCl}$. These values were set according to the $\mathrm{NaCl}$ average value $(10,782 \mathrm{mg} / \mathrm{L})$ found in the wastewater characterization (Table 1 ) and the most likely variation range of their concentrations. Fig. 3 shows the sample biodegradability as a function of $\mathrm{NaCl}$ concentration, being possible to observe that, keeping unchanged the other parameters, the sample biodegradability decreases as the $\mathrm{NaCl}$ concentration increases. Table 5 shows the results obtained in the R tests carried out for these samples with different $\mathrm{NaCl}$ concentrations. One of the values that stands out is the toxicity verified in the sample with $\mathrm{NaCl}$ concentration of $30,000 \mathrm{mg} / \mathrm{L}$ (3.2\%), which had not been previously observed in any sample, even in the sample 03/18/2014 $\mathrm{AM}$, which has a $\mathrm{NaCl}$ concentration of about $36,000 \mathrm{mg} / \mathrm{L}$. However, since these wastewaters have a composition high variable and that there is a large influence of the different parameters on their biological degradation, either individually, or by their interaction, one must pay attention on the toxicity of this type of wastewaters when they have $\mathrm{NaCl}$ concentrations higher than $17,500 \mathrm{mg} / \mathrm{L}$.

Thus, looking at all values obtained from the $\mathrm{R}$ tests and at the kinetic constant obtained by fitting a pseudo-first order kinetic model to the experimental data, one can conclude that the values of $R s, U, q$ and $k$ decrease when increasing the $\mathrm{NaCl}$ concentration. The difference between the results obtained for the lowest $\mathrm{NaCl}$ concentrations and the $\mathrm{NaCl}$ concentration of $17,500 \mathrm{mg} / \mathrm{L}$ is not very large (about 5\%), but when the $\mathrm{NaCl}$ concentration is increased to $30,000 \mathrm{mg} / \mathrm{L}$, the difference becomes significant (about 25\%). This

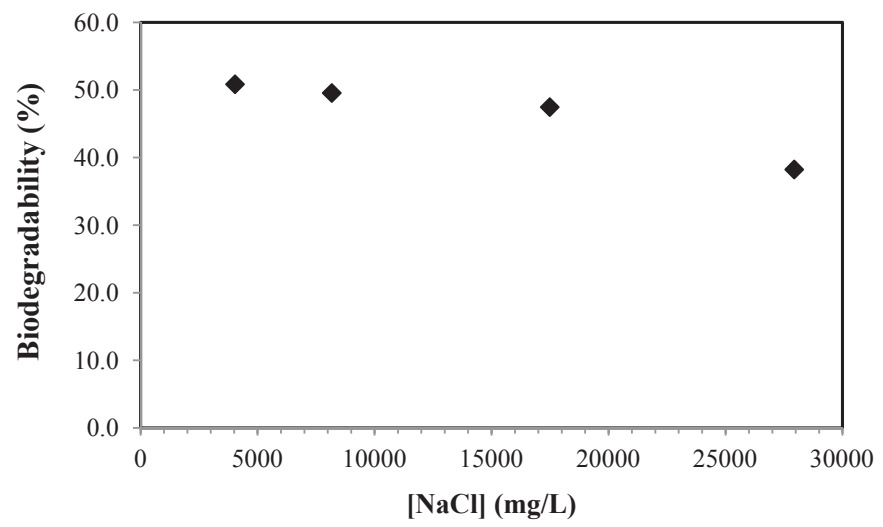

Fig. 3. Fish canning industry wastewater aerobic biodegradability regarding $\mathrm{NaCl}$ content. 
Table 5

Aerobic respirometric results obtained with the 03/31/2014 C fish canning industry wastewater sample with different $\mathrm{NaCl}$ dosages.

\begin{tabular}{|c|c|c|c|c|}
\hline \multirow[t]{2}{*}{ Parameter } & \multicolumn{4}{|l|}{ Samples } \\
\hline & $03 / 31 / 2014 \mathrm{C}$ & $8 \mathrm{~g} / \mathrm{L} \mathrm{NaCl}$ & $17.5 \mathrm{~g} / \mathrm{L} \mathrm{NaCl}$ & $30 \mathrm{~g} / \mathrm{L} \mathrm{NaCl}$ \\
\hline $\mathrm{COD}\left(\mathrm{mgO}_{2} / \mathrm{L}\right)$ & 4759 & 4759 & 4759 & 4759 \\
\hline $\mathrm{O} \& \mathrm{G}(\mathrm{mg} / \mathrm{L})$ & 1962 & 1962 & 1962 & 1962 \\
\hline $\mathrm{NaCl}(\mathrm{mg} / \mathrm{L})$ & 4035 & 8169 & 17,484 & 27,934 \\
\hline R_Biodegradability (\%) & 50.9 & 49.6 & 47.5 & 38.2 \\
\hline R_Toxicity (\%) & 0.0 & 0.0 & 0.0 & 3.2 \\
\hline $\mathrm{Rs}\left(\mathrm{mgO}_{2} / \mathrm{L} \mathrm{h}\right)$ & 38.7 & 33.7 & 22.7 & 13.7 \\
\hline $\mathrm{CO}\left(\mathrm{mgO}_{2} / \mathrm{L} \mathrm{h}\right)$ & 799 & 782 & 745 & 601 \\
\hline $\mathrm{bCOD}\left(\mathrm{mgO}_{2} / \mathrm{L} \mathrm{h}\right)$ & 2420 & 2370 & 2259 & 1820 \\
\hline $\mathrm{U}\left(\mathrm{mg}_{\mathrm{bcoD}} / \mathrm{L} \mathrm{h}\right)$ & 2132 & 1996 & 1475 & 816 \\
\hline $\mathrm{q}\left(\mathrm{mg}_{\mathrm{bCOD}} / \mathrm{mgVSS} . \mathrm{d}\right)$ & 20.4 & 17.6 & 11.4 & 6.3 \\
\hline$k\left(\mathrm{~h}^{-1}\right)$ & 1.702 & 0.822 & 0.498 & 0.317 \\
\hline
\end{tabular}

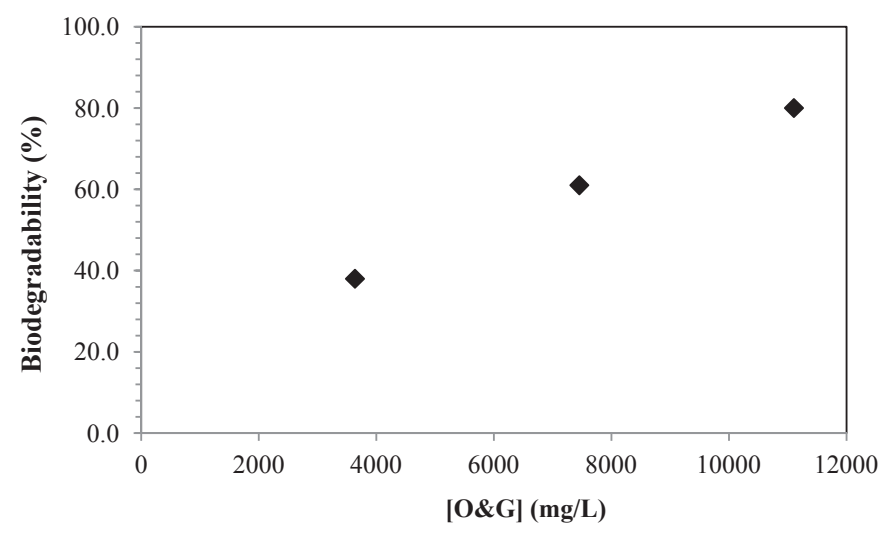

Fig. 4. Fish canning industry wastewater aerobic biodegradability regarding $O \& G$ content.

way, it is possible to conclude that $\mathrm{NaCl}$ is an inhibitor of aerobic biological treatment of fish canning industrial wastewater, essentially for dosages higher than $17,500 \mathrm{mg} / \mathrm{L}$. The higher the $\mathrm{NaCl}$ amount in the effluent, the smaller the organic matter quantity degraded and the lower the degradation rate. It is well known from the literature that the high salinity of wastewaters strongly inhibits their aerobic biological treatment. The influence of this parameter has been studied by several authors who concluded that there is actually a negative effect on aerobic wastewater treatment if the $\mathrm{NaCl}$ concentration is above $5000-8000 \mathrm{mg} / \mathrm{L}$ (Intrasungkha et al., 1999). Nevertheless, the good performance of the activated sludge system was mentioned by Aloui et al. (2009), Wang et al. (2005) and Linarić et al. (2013) who reported a BOD considerable

\section{Table 6}

Aerobic respirometric results obtained with the 04/14/2014 C fish canning industry wastewater sample with different $O \& G$ dosages.

\begin{tabular}{lccc}
\hline \multirow{2}{*}{ Parameter } & \multicolumn{3}{l}{ Samples } \\
\cline { 2 - 4 } & $04 / 14 / 2014 \mathrm{C}$ & $7.5 \mathrm{~g} / \mathrm{L}$ O\&G & $3.6 \mathrm{~g} / \mathrm{L} \mathrm{O \& G}$ \\
\hline $\mathrm{COD}\left(\mathrm{mgO}_{2} / \mathrm{L}\right)$ & 17,048 & 13,132 & 7900 \\
$\mathrm{O} \& \mathrm{mg} / \mathrm{L})$ & 11,103 & 7452 & 3635 \\
$\mathrm{NaCl}(\mathrm{mg} / \mathrm{L})$ & 9570 & 9570 & 9570 \\
$\mathrm{R} \_$Biodegradability $(\%)$ & 80.0 & 61.0 & 38.0 \\
$\mathrm{R}$ Toxicity $(\%)$ & 0.0 & 0.0 & 0.0 \\
$\mathrm{Rs}\left(\mathrm{mg}_{\mathrm{O} 2} / \mathrm{L} \mathrm{h}\right)$ & 64.5 & 47.2 & 34.0 \\
$\mathrm{CO}\left(\mathrm{mg}_{\mathrm{O} 2} / \mathrm{L} \mathrm{h}\right)$ & 4497 & 2645 & 984 \\
$\mathrm{bCOD}\left(\mathrm{mgO}_{2} / \mathrm{L} \mathrm{h}\right)$ & 13,626 & 8015 & 2980 \\
$\mathrm{U}\left(\mathrm{mg}_{\mathrm{bcoD}} / \mathrm{L} \mathrm{h}\right)$ & 3903 & 2762 & 1956 \\
$\mathrm{q}\left(\mathrm{mg}_{\mathrm{bcoD}} / \mathrm{mg}_{\mathrm{vss}} \mathrm{d}\right)$ & 29.2 & 22.1 & 15.3 \\
$k\left(\mathrm{~h}^{-1}\right)$ & 0.346 & 0.89 & 1.3 \\
\hline
\end{tabular}

reduction due to the combined effect of wastewater high salinity and high organic load. However, as it happens in this work, the organic contamination reduction rates decreased with the increase of $\mathrm{NaCl}$ content. Although the adaptation of activated sludge has already proved to be possible, a major bottleneck is that the proper performance of such salt-adapted systems is usually limited to less than $5 \%$ of salt. In fact, Dinçer and Kargi (2001) reported a COD removal efficiency from a saline wastewater by a rotating biological contactor of $90 \%$ for salt concentrations $<3 \%$; however, the efficiency dropped to 85 and $60 \%$ for 5 and $10 \%$ of salt concentrations, respectively.

The sample chosen to study the O\&G dosage influence on fish canning wastewater aerobic biological treatment was the sample $04 / 14 / 2014 \mathrm{C}$, wherein the O\&G amount is high and the $\mathrm{NaCl}$ concentration is relatively low. To achieve three different O\&G concentrations, two floatable O\&G portions were removed from the original wastewater sample surface. Fig. 4 shows the samples biodegradability as a function of the $O \& G$ concentration, being possible to verify that the lower this amount, the lower the percentage of biodegradability. It must be noted that, unlike what happened with the $\mathrm{NaCl}$ concentration variation, in which only the sample $\mathrm{NaCl}$ dosage was changed, in this case, when removing some $\mathrm{O \& G}$ of the sample surface, some organic matter is also being removed, meaning that the sample COD values also changed. Thus, this test does not allow to draw conclusions as reliable as in the case of $\mathrm{NaCl}$ dosage influence tests. Table 6 shows the O\&G and COD concentrations for each new sample analyzed and the respective percentages of biodegradability and toxicity, being possible to verify that the percentage of biodegradability decreases from the original sample to the other, more than the respective COD/O\&G ratio. Table 6 shows also the results obtained in the $R$ tests and the kinetic constants achieved from the adjustment of the pseudo-first order kinetic model to the experimental data. It is possible to see that as the $O \& G$ dosage decreases, the respiration rate $(R s)$ also decreases, as well as the bCOD degradation rate $(U)$. This reduction may also be due to the decrease in the sample pollutant load, making difficult to say with certainty that the lower the O\&G dosage, the lower the percentage of the wastewater biodegradability. Regarding the kinetic constant determined by fitting a pseudo-first kinetic model to the experimental data, it was found that, in this case, it increases with the reduction of O\&G dosage, probably due to the formation of O\&G floating aggregates in the case of high O\&G dosage, that may cause some inhibition in the microorganisms' activity. However, it has to be noted that, depending on the O\&G type present in industrial wastewaters, microorganisms could respond differently during the degradation process. Primasari et al. (2011) studied the feasibility of an aerobic biological process to treat oily wastewater from palm oil food industry and found that higher sludge concentrations led to higher O\&G removal while moderate sludge concentration led to better results in COD removal. In fact, oil and greases are known to be, generally, biodegradable and, thus, regarded as part of the organic load which is treated (Sunny and Mathai, 2013). Other authors also studied the treatment of highly oily wastewaters and reached similar conclusions. On the other hand, Chipasa and Medrzycka (2008) also verified the high ability of lipids to form floating aggregates, thereby hindering the wastewater biological treatment.

\section{Conclusions}

A respirometric technique was used to study the $\mathrm{NaCl}$ and $\mathrm{O} \& \mathrm{G}$ effects on aerobic biological treatment of fish canning industrial wastewaters. It was found that above $17.5 \mathrm{~g} / \mathrm{L}$ of $\mathrm{NaCl}$ the inhibition is detectable, but for lower dosages the aerobic biological treatment was not affected. The O\&G content proved not to be an activated 
sludge treatment process inhibitor since higher degradation rates were found for higher dosages.

This work showed that, in addition to be useful tools for activated sludge plants design, respirometric tests can effectively contribute to better understand the activated sludge process behavior, allowing early detection of potential inhibitory effects on real wastewater treatment plants, thus avoiding biomass damages.

\section{Acknowledgments}

This work was co-financed by FCT/MEC and FEDER under Programe PT2020 (Project UID/EQU/50020/2013), by QREN, ON2 and FEDER (Project NORTE-07-0162-FEDER-000050) and by ValorPeixe - Valorização de Subprodutos e Águas Residuais da Indústria de Conservas de Peixe, project in co-promotion I\&DT QREN, $\mathrm{n}^{\circ} 13634$ financed by FEDER through POFC - Programa Operacional Factores de Competitividade for which the authors are thankful. The authors also wish to thank the cannery in study for wastewater samples. Raquel O. Cristóvão thanks FCT for the Post-doc Scholarship (SFRH/ BPD/81564/2011).

\section{References}

APHA, 2012. Standard Methods for the Examination of Water and Wastewater, twenty-second ed. Washington, DC., United States of America.

Aloui, F., Khoufi, S., Loukil, S., Sayadi, S., 2009. Performances of an activated sludge process for the treatment of fish processing saline wastewater. Desalination 248, 68-75.

Ballesteros Martín, M.M., Casas López, J.L., Oller, I., Malato, S., Sánchez Perex, J.A. 2010. A comparative study of different tets for biodegradability enhancement determination during AOP treatment of recalcitrant toxic aqueous solutions. Ecotoxicol. Environ. Saf. 73, 1189-1195.

Cavaleiro, A., Salvador, A., Alves, J., Alves, M.M., 2009. Continuous high rate anaerobic treatment of oleic acid based wastewater is possible after a step feeding start-up. Environ. Sci. Technol. 43, 2931-2936.

Chipasa, K.B., Medrzycka, K., 2008. Characterization of the fate of lipids in activated sludge. J. Environ. Sci. 20, 536-542.

Chowdhury, P., Viraraghavan, T., Srinivasan, A., 2010. Biological Treatment Processes for Fish Processing Wastewater. Faculty of Engineering, University of Regina, Canada.

Cristóvão, R.O., Botelho, C.M., Martins, R.J.E., Loureiro, J.M., Boaventura, R.A.R., 2015 Fish canning industry wastewater treatment for water reuse - a case study J. Clean. Prod. 87, 603-612.

Dinçer, A.R., Kargi, F., 2001. Performance of rotating biological disc system treating saline wastewater. Process Biochem. 36, 901-906.

Hoffman, J., Reznicekova, I., Vanokova, S., Kupec, J., 1997. Manometric determination of biological degradability of substances poorly soluble in aqueous environments. Int. Biodeterior. Biodegr. 39, 327-332.
Hufschmid, A., Becker-Van Slooten, K., Strawczynski, A., Vioget, P., Parra, S., Péringer, P. Pulgarin, C., 2003. BOD5 measurements of water presenting inhibitory $\mathrm{Cu} 2+$. Implications in using of BOD to evaluate biodegradability of industrial wastewaters. Chemosphere 50, 171-176.

Intrasungkha, N., Keller, J., Blackall, L.L., 1999. Biological nutrient removal efficiency in treatment of saline wastewater. Water Sci. Technol. 39, 183-190.

Kargi, F., Uygur, A., 1996. Biological treatment of saline wastewater in an aerated percolator unit utilizing halophilic bacteria. Environ. Technol. 17, 320-325.

Kokabian, B., Bonakdarpour, B., Fazel, S., 2013. The effect of salt on the performance and characteristics of a combined anaerobic-aerobic biological process for the treatment of synthetic wastewaters containing Reactive Black 5. Chem. Eng. J. $221,363-372$.

Kungolos, A., 2005. Evaluation of toxic properties of industrial wastewater using online respirometry. J. Environ. Sci. Health, Part A 40, 869-880.

Linarić, M., Markić, M., Sipos, L., 2013. High salinity wastewater treatment. Water Sci. Technol. 68, 1400-1405.

Mahendraker, V., Viraraghavan, T., 1995. Respirometry in environmental engineering. J. Environ. Sci. Health. Part A. Environ. Sci. Eng 30, 713-734.

Metcalf, L., Eddy, H.P., 1995. Wastewater Engineering: Treatment, Disposal, and Reuse, third ed. 224-283, 436-488, 677-688, 920-944.

Nakhla, G., Liu, V., Bassi, A., 2006. Kinetic modeling of aerobic biodegradtion of high oil and grease rendering wastewater. Biores. Technol. 97, 131-139.

NovaTec Consultants Inc and EVS Environmental Consultants, 1994. Wastewater Characterization of Fish Processing Plant Effluents - a Report to Water Quality/ Waste Management Committee. Fraser River Estuary Management Program. Waste Management. www.rem.sfu.ca/FRAP/9339.pdf.

Panswad, T., Anan, C., 1999. Impact of high chloride wastewater on an anaerobic anoxic/aerobic process with and without inoculation of chloride acclimated seeds. Water Res. 33, 1165-1172.

Pernetti, M., Di Palma, L., 2005. Experimental evaluation of inhibition effects of saline wastewater on activated sludge. Environ. Technol. 26, 695-703.

Prasertsan, P., Jung, S., Buckle, K.A., 1994. Anaerobic filter treatment of fishery wastewater. World J. Microb. Biotechnol. 10, 11-13.

Primasari, B., Ibrahim, S., Annuar, M.S.M.A., Remmie, L.X.I, 2011. Aerobic treatment of oily wastewater: effect of aeration and sludge concentration to pollutant reduction and PHB accumulation. World Acad. Sci. Eng. Technol. 5, 850-854.

Ramalho, R.S., 1977. Introduction to Wastewater Treatment Processes. Laval University, Quebec, Canada, p. 185.

Ricco, G., Tomei, M.C., Ramadori, R., Laera, G., 2004. Toxicity assessment of common xenobiotic compounds on municipal activated sludge: comparison between respirometry and Microtox. Water Res. 38, 2103-2110.

Shogren, R.L., PEtrovic, Z., Liu, Z., Erhan, S.Z., 2004. Biodegradation behaviour of some vegetable oil-based polymers. J. Polym. Environ. 12, 173-178.

Sunny, N., Mathai, L., 2013. Physicochemical process for fish processing wastewater. Int. J. Innov. Res. Sci. Eng. Technol. 2, 901-905.

Technical Report Series FREMP WQWM-93-10, DOE FRAP 1993-39, 1994. Wastewater Characterization of Fish Processing Plant Effluents. Fraser River Estuary Management Program, New West Minister, B. C.

Wang, J.-L., Zhan, X.-M., Feng, Y.-C., Qian, Y., 2005. Effect of salinity variations on the performance of activated sludge system. Biomed. Environ. Sci. 18, 5-8.

Zhan, X-m., Wang, J-l., Wen, X-h., Feng, Y-c., Oian, Y., 2000. Influence of inorganic salt on aerobic biodegradability of dyestuffs. J. Environ. Sci. 12, 416-421. 